\title{
Tree-rings and people - different views on the 1540 Megadrought. Reply to Büntgen et al. 2015
}

Christian Pfister $^{1}$ - Oliver Wetter ${ }^{1,2}$ - Rudolf Brázdil ${ }^{12,13}$.

Petr Dobrovolný $^{12,13}$ - Rüdiger Glaser ${ }^{16}$ - Jürg Luterbacher ${ }^{3}$.

Sonia I. Seneviratne ${ }^{5}$ - Eduardo Zorita ${ }^{4}$ - Maria-Joao Alcoforado 8 .

Mariano Barriendos ${ }^{10,9}$ - Ursula Bieber ${ }^{11}$ - Karl H. Burmeister ${ }^{14}$.

Chantal Camenisch $^{1,2}$ - Antonio Contino ${ }^{15}$ - Uwe Grünewald ${ }^{7}$.

Jürgen Herget $^{6}$ - Iso Himmelsbach ${ }^{16}$. Thomas Labbé ${ }^{19}$.

Danuta Limanówka $^{20}$ - Laurent Litzenburger ${ }^{21}$ - Andrea Kiss ${ }^{17}$.

Oldřich Kotyza $^{18}$ • Øyvind Nordli ${ }^{22}$ - Kathleen Pribyl ${ }^{23}$ - Dag Retsö ${ }^{24}$.

Dirk Riemann $^{16}$ - Christian Rohr ${ }^{1,2}$ - Werner Siegfried ${ }^{25}$.

Jean-Laurent Spring ${ }^{26}$ • Johan Söderberg ${ }^{24}$ • Sebastian Wagner ${ }^{4}$.

Johannes P. Werner ${ }^{3}$

Received: 9 January 2015 / Accepted: 29 April 2015 /Published online: 27 May 2015

(C) Springer Science+Business Media Dordrecht 2015

Büntgen et al. (2015; hereinafter B15) present the result of new research which question the results of Wetter et al. 2014, ( hereinafter W14) and Wetter et al. (2013, hereinafter W13) regarding European climate in 1540. B15 conclude from tree-ring evidence that the results based on documentary data of W14 "probably overstated the intensity and duration of the 1540

This reply refers to the comment available at: http://dx.doi.org/10.1007/s10584-015-1423-1.

Oliver Wetter

oliver.wetter@hist.unibe.ch

Christian Pfister

christian.pfister@hist.unibe.ch

Rudolf Brázdil

brazdil@sci.muni.cz

Rüdiger Glaser

ruediger.glaser@geographie.uni-freiburg.de

Jürg Luterbacher

juerg.luterbacher@geogr.uni-giessen.de

Sonia I. Seneviratne

sonia.seneviratne@env.ethz.ch

Eduardo Zorita

eduardo.zorita@hzg.de 
drought event." W14 termed it "Megadrought" because of its extreme duration and spatial extent compared to other drought events in central Europe, although they note that the term is generally used for decadal rather than for single-year droughts (Seneviratne et al. 2012).

We take the opportunity to recall the following issues. Firstly, when dealing with drought the complexity of this phenomenon should be kept in mind. Meteorological drought defined as a large negative precipitation anomaly during a certain period can trigger agricultural, hydrological, groundwater and socioeconomic droughts. Lloyd-Hughes (2013 and references cited herein) concluded that any workable objective definition of drought does not exist. To quantify

\author{
Maria-Joao Alcoforado \\ mjalcoforado@campus.ul.pt \\ Mariano Barriendos \\ mbarriendos@ub.edu \\ Ursula Bieber \\ ursula.bieber@sbg.ac.at
}

Karl H. Burmeister

k.h.a.burmeister@web.de

Antonio Contino

ntncontino@gmail.com

Uwe Grünewald

uwe.gruenewald@tu-cottbus.de

Jürgen Herget

herget@giub.uni-bonn.de

Thomas Labbé

labbe@pg.tu-darmstadt.de

Danuta Limanówka

danuta.limanowka@imgw.pl

Laurent Litzenburger

1.litzenburger@free.fr

Andrea Kiss

kiss@hydro.tuwien.ac.at

Oldřich Kotyza

muzeum.ltm@telecom.cz

Øyvind Nordli

oyvind.nordli@met.no

Kathleen Pribyl

k.pribyl@uea.ac.uk

Dag Retsö

dag.retso@lai.su.se

Jean-Laurent Spring

jean-laurent.spring@agroscope.admin.ch

Johan Söderberg

johan.soderberg@ekohist.su.se

Johannes P. Werner

johannes.werner@geogr.uni-giessen.de 
droughts, various indices based on precipitation, temperature and evapotranspiration are used such as the Standardized Precipitation Index (SPI), Standardized Precipitation Evapotranspiration Index (SPEI), Z- index and PDSI. Their calculation depends on different periods (seasons, combination of months) and so different indices may classify the same drought episode differently (e.g. Brázdil et al. 2014).

Secondly, there is no mention in W14 of an "inability of natural proxy archives to record climate extremes," as claimed in B15. Rather, W14 state "Palaeo-climatic evidence of the natural archives, such as tree-rings or grape harvest dates, may fail to detect record-breaking climatic outliers, whereas archives of society usually describe them in most accurate detail." In general human observations deal with weather, not climate, and distinguish between effects of temperature and precipitation on time-scales of days, weeks and months. Such detailed

1 Oeschger Centre for Climate Change Research, University of Bern, Bern, Switzerland

2 Institute of History, Section of Economic, Social and Environmental History (WSU), University of Bern, Länggassstrasse 49, Bern 3000 9, Switzerland

3 Department of Geography; Climatology, Climate Dynamics and Climate Change, Justus Liebig University of Giessen, Senckenbergstrasse 1, 35390 Giessen, Switzerland

4 Helmholtz Centre Geesthacht, Institute of Coastal Research, Max-Planck-Strasse 1, 21502 Geesthacht, Germany

5 Institute for Atmospheric and Climate Science, ETH Zurich CHN N11, Universitätstrasse 16, 8092 Zurich, Switzerland

6 Department of Geography, Rheinische Friedrich Wilhelms University, Meckenheimer Allee 166, D-53115 Bonn, Germany

7 Chair Hydrology and Water Resources Management, Faculty of Environmental Sciences and Process Engineering, Brandenburg University of Technology Cottbus, Senftenberg,

Konrad-Wachsmann-Allee 6, 03046 Cottbus, Switzerland

8 Centre of Geographical Studies, Institute of Geography and Planning, University of Lisbon, Edifício da Fac. de Letras, Alameda da Universidade, 1600-214 Lisbon, Portugal

Catalan Institute for Climate Sciences (IC3), Doctor Trueta 203, 08005 Barcelona, Spain

Department of Modern History, University of Barcelona, Montalegre 6, 08003 Barcelona, Spain

Department of Slavonic Studies and Interdisciplinary Centre of Medieval Studies, University of Salzburg, Erzabt-Klotz-Strasse 1, 5020 Salzburg, Austria

Institute of Geography, Masaryk University, Kotlárská 2, 61137 Brno, Czech Republic

Global Change Research Centre AS CR, Bělidla 956/4a, 60300 Brno, Czech Republic

Department of Earth and Sea Sciences (DiSTeM), University of Palermo, Via Archirafi 26, 90123 Palermo, Italy

16 Department of Environmental Social Studies and Geography - Physical Geography, Albert-Ludwigs University Freiburg i.Br, Werthmannstrasse 4, 79102 Freiburg, Germany

17 Institute of Hydraulic Engineering and Water Resources Management, Vienna University of Technology, Karlsplatz 13, 1040 Vienna, Austria

18 Regional Museum, Dlouhá 139, 41201 Litoměřice, Czech Republic

19 Institute of History, Technische Universität (TU) of Darmstadt, Residenzschloss, 64283 Darmstadt, Germany 
information is needed for decision-making on preventive measures to be taken about low probability outcomes with large consequences, as adaptation is place- and context specific (IPCC SPM-1 2014).

Our reconstruction of the 1540 Megadrought is supported by four different kinds of evidence. The first type consists of the direct mention of drought by more than 300 contemporary chroniclers originating from Austria, Belgium, the Czech Republic, England, France, Germany, Hungary, Italy, the Netherlands, Poland, Romania, Slovakia, Spain, Sweden and Switzerland, who report the number and the temporal distribution of days with precipitation or short rain-spells in that year. These memories retained risk information of extreme events for future generations in documents created for humans by humans, comprehensible to everyone, without recourse to sophisticated statistics. In 1540, chroniclers were concerned about the lack of precipitation and the consequent impacts, such as the extremely low levels of large rivers and lakes, the drying out of fountains, brooks and smaller rivers, the extreme soil desiccation, the depletion of groundwater resources, cattle dying from thirst, hunger and heat-stroke, and the withering of legumes, vines and trees, which are all described in detail. Reports about widespread forest fires raging from the Vosges Mountains (France) to the Carpathians (Hungary) are of particular significance for assessing the unique severity of heat and drought (W14).

The second type of documentary weather source is the records of local authorities concerning measures taken in the face of heat and drought. A third source is the weather diary kept by Cracow University rector Marcin Biem. His daily records were used to statistically reconstruct precipitation for Cracow for 1540 (W14). For the core region of the drought, i.e. Eastern France, Switzerland, Southern Germany, the Czech Republic and Northern Italy, consistent documentary evidence is available on meteorological, hydrological, hydrogeological, agricultural and socio-economic drought. Finally, spring-summer (AMJJ) temperatures in 1540 were assessed from a new series of grape harvest dates (1444-2011) for Switzerland including phenological observations on the early maturity of grapes (W13).

We consider that the manifold pieces of the climatic puzzle for 1540 provided by documentary evidence, scattered over a space of 2 to 3 million $\mathrm{km}^{2}$, fit perfectly together, providing a coherent picture of the large-scale weather situation. Likewise, the rain-day evidence from Switzerland and Poland used to assess seasonal precipitation in 1540 yields results in the same order of magnitude (W14). Results of the documentary index-based reconstruction of temper-

20 Institute of Meteorology and Water Management National Research Institute (IMGW-PIB), Center for Poland's Climate Monitoring, Podleśna, 01-673 Warsaw, Poland

21 Lorraine University Center for Historical Research (CRULH), University of Lorraine, Campus Lettres et Sciences Humaines, Place Godefroy de Bouillon, BP 3397, 54015 Nancy Cedex, France

22 Research and Development Department, Division for Model and Climate Analysis, Norwegian Meteorological Institute, Henrik Mohns plass 1, P.O. Box 43, Blindern N-0313, Norway

23 Climatic Research Unit, School of Environmental Sciences, University of East Anglia, Norwich Research Park, Norwich NR4 7TJ, UK

24 Department of Economic History, Stockholm University, SE-106 91 Stockholm, Sweden

25 Agroscope Research Station ACW, Extension Wine, Schloss 1 Postfach, 8820 Wädenswil, Switzerland

26 Station de recherche Agroscope à Pully, 21 av. de Rochettaz, CH-1009 Pully, Switzerland 
ature for Central Europe (Dobrovolný et al. 2010) and reconstruction of precipitation for the Czech Lands since 1500 (Dobrovolný et al. 2015) confirm the picture. 1540 stands out as being the driest of the 510 summers from 1501 to 2010 as well as the driest year in the territory of the Czech Lands. The year 1540 was also the warmest in the Central Europe temperature series (Table 1).

The heat of summer 1540 ranks only behind that of 2003 in central Europe, but it should be kept in mind that the maxima/minima of documentary temperature indices are limited to departures of $+/-1.8$ standard deviations from normal (Dobrovolný et al. 2010). Therefore, they are not well suited to indicate outstanding temperatures. Finally, the combination of extreme heat and drought is physically consistent considering the role of soil moisture deficits for the generation of heat waves (e.g. Seneviratne et al. 2010; Müller and Seneviratne 2012).

It should be noted that observers from Germany report several days of rainfall after 10 August (Gregorian style), which caused floods in the Main, middle Rhine, Elbe and Danube River systems (Glaser et al. 2010, data from tambora.org). No flood is reported from the Austrian Danube catchment (Rohr 2007). This spell of rain may have provided enough water to support continued growth in the trees in the regions concerned. Observers in Alsace and in Switzerland, however, report only a slight spell of rain for two or 3 days (W14). In general, this spell of rain may have broken the peak of the heat-wave, but drought set in again persisting until the end of the year.

Only a few papers (e.g. Büntgen et al., 2010, Büntgen et al. 2011a) compare extreme values, indicating both wet and dry conditions, between TRW (Tree Ring Width) and documentary or instrumental data. Results from these papers, complemented by data from Dobrovolný et al. (2014) were used in constructing Fig. 1, which shows the top twenty negative TRW deviations (indicating drought) from sampled sites in the region between France and Slovakia for each of the studies cited above. B11a, B11b and D14 only have 4 years in common: 1525, 1616, 1636 and 1653. The order of individual years in each chronology also varies. While there are some years with agreement between negative TRW and documentary or instrumental data, other years disagree or are inconsistent. Thus a general agreement in dry years is lacking. The question thus arises of to what extent extreme years derived from various TRW chronologies are representative and stable.

Büntgen et al. (2011b hereinafter B11b) used a large sample of " 11,873 annually resolved and absolutely dated ring width (TRW) measurement series from fir (Abies alba Mill.) trees spanning the 962 to 2007 period across France, Switzerland, Germany and the Czech Republic." The authors compared 97 extreme departures in fir growth to temperature and precipitation indices and instrumental measurements for spring (MAM) and summer (JJA) from Germany, Switzerland and the Czech Republic. Negative TRW extremes mainly coincided with dry and temperate springs as well as dry and warm summers, while positive TRW

Table 1 Comparison of rank of 2003 temperature (warm) and precipitation (dry) springs, summers, autumns and years patterns in the Czech Lands with 1540 (Dobrovolný et al. 2010, 2015)

\begin{tabular}{llrrrr}
\hline Year & Temp./ Prec. & MAM rank & JJA rank & SON rank & YEAR rank \\
\hline 1540 & Temp & 3rd & 2 nd & 3rd & 1 st \\
1540 & Prec & 9 th & $1 \mathrm{st}$ & 12 th & 1 st \\
2003 & Temp & 18 th & $1 \mathrm{st}$ & 169 th & 7 th \\
2003 & Prec & 159 th & 28th & 187 th & 40 th \\
\hline
\end{tabular}




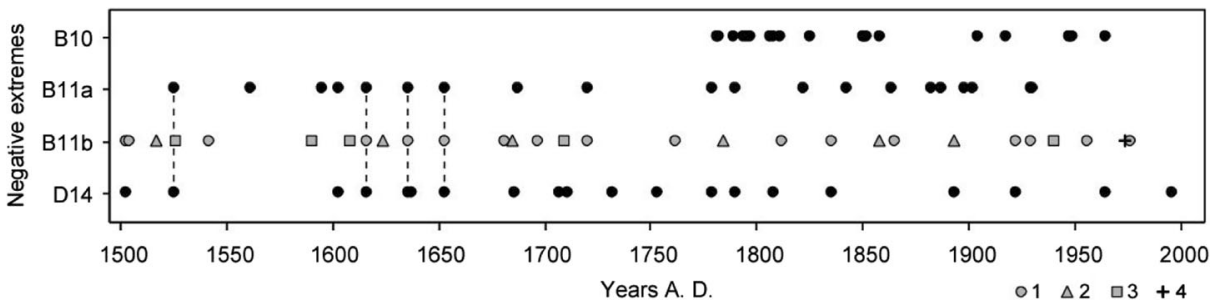

Fig. 1 Comparison of years with 20 most negative deviations in TRW series after AD 1500: B10 - Büntgen et al. (2010a), pine (Pinus sylvestris), Slovakia, JJA PDSI, 1744-2006; B11a - Büntgen et al. (2011a), fir (Abies alba Mill.), Southern Moravia, MJ Z-index, 1500-2007; B11b - Büntgen et al. (2011b), fir (Abies alba Mill.), Central Europe, A.D. 962-2007; D14 - Dobrovolný et al. (2014), oak (Quercus sp), Czech Lands, A.D. 15012010. Explanation for B11b: 1 (all) - France, Switzerland, Germany, Czech Lands; 2 - (West-Mid) France, Switzerland, Germany, 3 - (Mid-East) Germany, 4 - (West-east) Germany, Czech Lands

extremes matched cooler and wetter spring and summer conditions. Well-known hot and dry extremes such as 1616, 1636 and 1976 (B11b) show negative TRW extremes in all series, while in some years the response of the rings to the drought lags for 1 year (B11b, Table 1). Tree growth may integrate effects from previous year climatic and ecological conditions leading to lagged autocorrelations (Frank et al. 2007). An example of a lagged TRW is 1720, which followed the hot and dry year 1719 (e.g., Pfister 1999; Brázdil et al. 2013). A small TRW is also seen in 1541, which B11a interpreted as a response to the severe drought in 1540. They point out that "the response shift [to 1540] is well in line with the high first order auto-correlative structure of the fir TRW data." This large sample of fir TRW measurements therefore confirms the existence of an extreme heat and drought in 1540 (B11b), in contrast to the result from the recent study from a somewhat larger number of different tree species led by the same author (B15). Likewise, the tree-ring study by Nicault et al. (2006) supports the existence of an extreme drought in 1540 in the large Mediterranean land area (Fig. 2).

The Letter of B15 leads to a discussion of the much wider issue of whether the summer of 2003 was indeed the hottest since 735, as B06 concluded from their analysis of a regional alpine valley series. On this point, Jolly et al. (2005) found a divergent vegetation growth

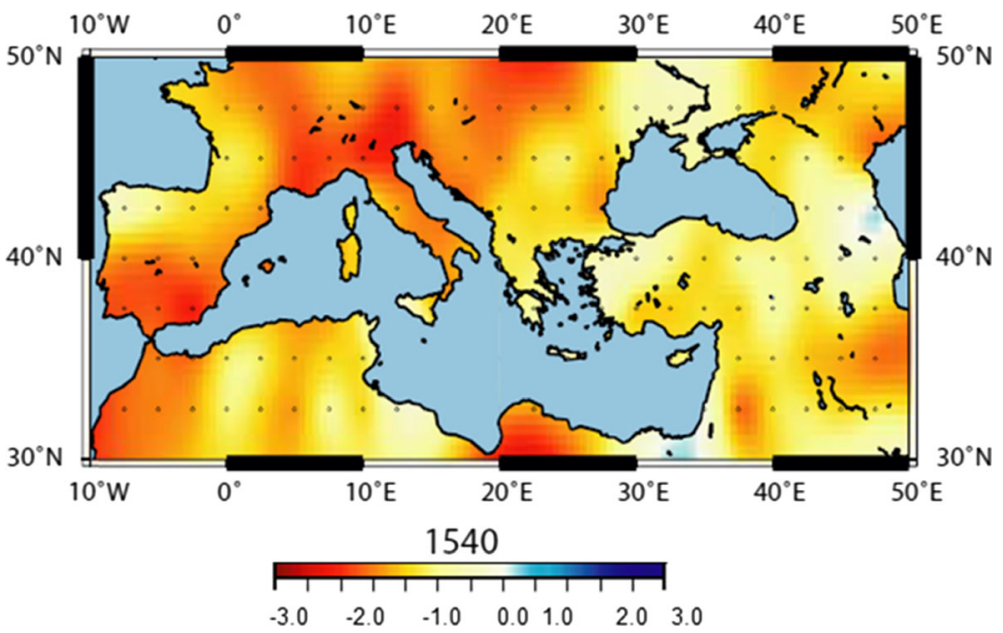

Fig. 2 Spatial pattern of PDSI over the Mediterrean basin for 1540 (Nicault et al. 2008) 
response during the 2003 event in the Swiss Alps characterized by high elevation growth enhancement and low elevation growth suppression in response to the extreme summer temperatures and low-altitude drought conditions. Their result suggests that the top MXD value for 2003 in the B06 paper may well be related to both extremely high temperatures and a substantial availability of moisture whereas earlier hot summers in Switzerland were dry (BUWAL 2004). In considering these different interpretations we should not forget that treerings are the only evidence available to document low-probability, high-impact events prior to the High Middle Ages in western and central Europe, and much later in other regions of the world. A systematic comparison of tree-ring extremes with documentary and instrumental extremes in the overlapping period is thus needed to get a detailed understanding of the response of tree species to extreme heat and drought.

Acknowledgments due to Victoria Slonosky for style corrections and to the Oeschger Centre for Climatic Change Research at the University of Bern for providing a workplace and logistic support.

\section{References}

Brázdil R, Dobrovolný P, Trnka M, Kotyza O, Řezníčková L, Valášek H, Zahradníček P, Štěpánek P (2013) Droughts in the Czech lands, 1090-2012 AD. Clim Past 9:1985-2002

Brázdil R, Trnka M, Mikšovský J, Řezníčková L, Dobrovolný P (2014) Spring-summer droughts in the Czech Land in 1805-2012 and their forcings. Int J Climatol. doi:10.1002/joc.4065

Büntgen U, Brázdil R, Frank D, Esper J (2010) Three centuries of Slovakian drought dynamics. Clim Dyn 35(2): 315-329. doi:10.1007/s00382-009-0563-2

Büntgen U, Brázdil R, Dobrovolný P, Trnka M, Kyncl T (2011a) Five centuries of Southern Moravian drought variations revealed from living and historic tree rings. Theor Appl Climatol 105(1-2):167-180. doi:10.1007/ s00704-010-0373-9

Büntgen U, Brázdil R, Heussner KU, Hoffmann J, Kontic R, Kyncl T, Pfister C, Chromá K, Tegel W (2011b) Combined dendro-documentary evidence of central European hydroclimatic springtime extremes over the last millennium. Quat Sci Rev 30:3947-3959

Dobrovolný P, Moberg A, Brázdil R, Pfister C, Glaser R, Wilson R, van Engelen A, Limanówka D, Kiss A, Halíčková M, Macková J, Riemann D, Luterbacher J, Böhm R (2010) Monthly, seasonal and annual temperature reconstructions for central Europe derived from documentary evidence and instrumental records since AD1500. Clim Chang 101:69-107

Dobrovolný P, Rybníček M, Koláŕ T, Brázdil, R., Trnka, M., Büntgen, U. (2014) A tree-ring perspective on the frequency and intensity of hydroclimate spring-summer extremes in the Czech Republic and the last 1250 years. Manuscript

Dobrovolný P, Brázdil R, Trnka M, Kotyza O, Valášek H (2015) Precipitation reconstruction for the Czech Lands, AD 1501-2010. Int J of Climatol. doi:10.1002/joc.3957

Frank D, Büntgen U, Böhm R, Maugeri M, Esper J (2007) Warmer early instrumental measurements versus colder reconstructed temperatures: shooting at a moving target. Quat Sci Rev 26:3298-3310

Bundesanstalt für Gewässerkunde (2006) Niedrigwasserperiode 2003 in Deutschland. Ursachen - Wirkungen Folgen. Mitteilungen 27, Koblenz

Glaser R, Riemann D, Schönbein J, Barriendos M, Brazdil R, Bertoli C, Camuffo D, Deutsch M, Dobrovolny P, van Engelen A, Enzi S, Halickova C, König S, König O, Limanowka D, Mackova J, Sghedoni M, Martin B, Himmelsbach I (2010) The variability of European floods since AD 1500 Climatic Change 101: 235-256.

IPCC SMP-1 (2014) IPCC Fifth Assessment Report. Climatic Change 2014. Approved Summary for Policymakers.

Jolly WM, Dobbertin M, Zimmermann ME, Reichstein M (2005) Divergent vegetation growth responses to the 2003 heat wave in the Swiss Alps. Geophys Res Lett 32:L18409. doi:10.1029/2005GL023252

Lloyd-Hughes B (2013) The impracticality of a universal drought definition. Theor Appl Climatol. doi:10.1007/ s00704-013-1025-7

Müller B, Seneviratne SI (2012) Hot days induced by precipitation deficits at the global scale. Proc Natl Acad Sci U S A 109(31):12398-12403. doi:10.1073/pnas.1204330109 
Nicault A, Alleaume Brewer S, Carrer M, Nola P, Guiot J (2008) Mediterranean drought fluctuation during the last 500 years based on tree-ring data. Clim Dyn 31:227-245. doi:10.1007/s00382-007-0349-3

Pfister C, (1999) Wetternachhersage. 500 Jahre Klimavariationen und Naturkatastrophen 1496-1995. Bern.

Rohr C (2007) Extreme Naturereignisse im Ostalpenraum. Naturerfahrung im Spätmittelalter und am Beginn der Neuzeit. Köln (Böhlau). 640+16 pp.

Seneviratne SI, Corti T, Davin EL, Hirschi M, Jaeger EB, Lehner I, Orlowsky B, Teuling AJ (2010) Investigating soil moisture-climate interactions in a changing climate: a review. Earth Sci Rev 99(3-4):125-161. doi:10. 1016/j.earscirev.2010.02.004

Seneviratne SI, Nicholls D, Easterling CM, Goodess S, Kanae J, Kossin Y, Luo J, Marengo K, McInnes M, Rahimi M, Reichstein A, Sorteberg, Vera C, Zhang X (2012) Changes in climate extremes and their impacts on the natural physical environment, in: Managing the Risks of Extreme Events and Disasters to Advance Climate Change Adaptation [Field CB, V Barros, TF Stocker, D Qin, DJ Dokken, KL Ebi, MD Mastrandrea, KJ Mach, GK Plattner, SK Allen, M Tignor and P.M. Midgley (eds.)]. A Special Report of Working Groups I and II of the Intergovernmental Panel on Climate Change, 109-230

Wetter O, Pfister C (2013) An underestimated record breaking event - why summer 1540 was likely warmer than 2003. Clim Past 9:41-59

Wetter O, Pfister C, Werner JP, Zorita E, Wagner S, Seneviratne SI, Herget J, Grünewald U, Luterbacher J, Alcoforado MJ, Barriendos M, Bieber U, Brázdil R, Burmeister KH, Camenisch C, Contino A, Dobrovolný P, Glaser R, Himmelsbach I, Kiss A, Kotyza O, Labbé T, Limanówka D, Litzenburger L, Nordli Ø, Pribyl K, Retsö D, Riemann D, Rohr C, Siegfried W, Söderberg J, Spring JL (2014) The year-long unprecedented European heat and drought of 1540 - a worst case. Clim Chang. doi:10.1007/s10584-014-1184-2 